\title{
Differences among assemblages of fish associated with Zostera capricorni and bare sand over a large spatial scale
}

\author{
Douglas J. Ferrell, Johann D. Bell \\ Fisheries Research Institute, New South Wales Agriculture and Fisheries, PO Box 21, Cronulla, NSW 2230, Australia
}

\begin{abstract}
This study addressed the question 'Does seagrass support a greater diversity and abundance of fish than bare sand over a large spatial scale?' The answer varied with both the measure used to describe the assemblages of fish, and the distance sand was from seagrass. Significantly more species were collected from Zostera capricorni than from sand at least $100 \mathrm{~m}$ from this seagrass in $89 \%$ of locations. At $58 \%$ of locations, Zostera also contained more species than sand within $10 \mathrm{~m}$ of the seagrass. When 2 species with very patchy distributions were excluded from analyses, Zostera held significantly more fish individuals than sand $>100 \mathrm{~m}$ away at $66 \%$ of locations. However, Zostera did not consistently contain more fish individuals than sand within $10 \mathrm{~m}$ of seagrass: Zostera had significantly more fish in $25 \%$ of locations, adjacent sand had more fish in $25 \%$ of locations and there were no differences in the remaining comparisons. Most of the common species were found predominantly in Zostera or the adjacent sand. There were prominent dissimilarities in relative abundance of species in samples from the 3 habitats, although samples from Zostera were more similar to those from adjacent sand than to those from sand $>100 \mathrm{~m}$ away. We conclude that (1) Zostera supported more species and individuals, and different species, than sand $>100 \mathrm{~m}$ from seagrass at a majority of locations, and (2) the fish assemblage associated with sand within $10 \mathrm{~m}$ of Zostera had fewer, and different, species than the seagrass at a majority of locations but supported as many individual fish as Zostera.
\end{abstract}

\section{INTRODUCTION}

It is widely reported that seagrass beds support different species, and a greater diversity and abundance, of fish than bare substrata (Kikuchi 1966, Branch \& Grindley 1979, Orth \& Heck 1980, Beckley 1983, Stoner 1983, Bell et al. 1987, Heck et al. 1989, Sogard 1989, and other references in Bell \& Pollard 1989). The structural complexity provided by seagrass shoots is thought to provide habitat, give protection from predators, and supply food in a way not available in the absence of seagrass (Kikuchi \& Peres 1977 , McRoy \& Helfferich 1980). With exception of protection from predators (see reviews by Orth et al. 1984 and Bell \& Pollard 1989), mechanisms that might explain how the properties of seagrass result in increased diversity and abundance of fauna are not well understood. Instead, comparative studies form much of the basis for the conclusion that seagrasses are 'better' places for fish than bare substrata.

In many cases the comparisons between vegetated and bare substrata have been limited. Sampling was either restricted to one sand or seagrass habitat at a site, or where more than one site was used, sampling was limited to one bay or estuary. These sampling weaknesses seem to have occurred because contrasts between seagrass and bare substrata were often not the main reason for the study (e.g. Kikuchi 1966, Orth \& Heck 1980, Beckley 1983, Stoner 1983, Bell et al. 1987 . Whitfield et al. 1989).

There are at least 4 reasons to question the generality of the conclusion that seagrasses support more fish than bare substrata. First, some assemblages of fish associated with bare areas have greater diversity and abundance than those found in Zostera seagrass beds (Hanekom \& Baird 1984, Heck \& Thoman 1984). Second, bare sand can support great densities of juvenile fish in its own right (Bennett 1989). Third, there is some evidence that diversity and abundance of fish associated with bare substrata can depend on proximity to vegetation. For example, collections of fish made on sand near seagrass beds (Sogard 1989), and the edges of accumulations of macrophytes (Robertson \& Lenanton 1984), contained more fish than samples taken from 
sand well away from vegetation. Fourth, some species of fish shelter in seagrass but feed over bare substrata (Robertson 1980, Summerson \& Peterson 1984).

Managers of estuaries are often faced with decisions about the relative importance of different substrata to fish. Because much of the existing data are equivocal, and limited to small spatial scales, decisions about the relative importance of seagrass and bare substrata as habitats for fish over large areas of coast cannot be made with confidence. Clearly, it is important to answer the question 'Does seagrass support a greater diversity and abundance of fish than bare sand over a large spatial scale?

Here, we answer this question by comparing assemblages of small fish from Zostera capricorni with those from sand at 3 locations in each of 4 Australian estuaries. At the same spatial scales, we also test whether sand adjacent to Zostera has the same assemblage of fish as sand hundreds of metres away.

\section{METHODS}

Study areas. We used 4 estuaries, spread over $300 \mathrm{~km}$ of the NSW coast for this study: Botany Bay, Port Hacking, Jervis Bay and Batemans Bay (Fig. 1). In each estuary, we sampled 3 habitats at each of 3 locations. The habitats were Zostera capricorni seagrass beds, bare sand within $10 \mathrm{~m}$ of the edge of such Zostera beds ('adjacent sand'), and bare sand between 100 and $1000 \mathrm{~m}$ from Zostera ('distant sand'). The 3 locations within an estuary were usually separated by at least $2 \mathrm{~km}$. All sampling was done in daylight hours between 12 March and 4 April 1989.
In all estuaries, Zostera beds were situated on the shallow fringe of the subtidal zone. The largest beds were about $150 \times 15 \mathrm{~m}$, but many were smaller, or fragmented into patches of 10 to $15 \mathrm{~m}$ in diameter interspersed with sand.

Collection of fish. We used a seine net made of knotless netting with a stretched mesh size of $6 \mathrm{~mm}$ to sample small species of fish, and juveniles of larger species. The seine did not have a 'cod end', and relied on the $2 \mathrm{~m}$ drop of the net to concentrate the catch. Sampling was done around low tide in 0.2 to $0.6 \mathrm{~m}$ of water. The area sampled by the net was $25 \mathrm{~m}^{2}$. This was done by placing 2 poles $5 \mathrm{~m}$ apart, pulling the net out $5 \mathrm{~m}$ from one pole (perpendicular to the line between the poles), and then walking the net around the remaining perimeter of the $5 \times 5 \mathrm{~m}$ square. The net was kept entirely within the habitat being sampled. Fish were caught by pursing the net.

At some locations, the shore dropped away more steeply and the Zostera beds were not always $5 \mathrm{~m}$ across. In these cases, the poles and the length of the net were used as a guide to estimate an equivalent area of seagrass.

At each location, 4 replicate hauls of the seine were made in each habitat. Hauls were made haphazardly within Zostera and adjacent sand habitats. Hauls within a habitat, and between Zostera and adjacent sand, were always separated by at least $5 \mathrm{~m}$. The distant sand habitat was sampled separately. Samples were fixed in $10 \%$ formalin and all fish were identified to species

Analysis of data. We used ANOVA to test the null hypothesis that there was no difference in the fish assemblages associated with Zostera, adjacent sand

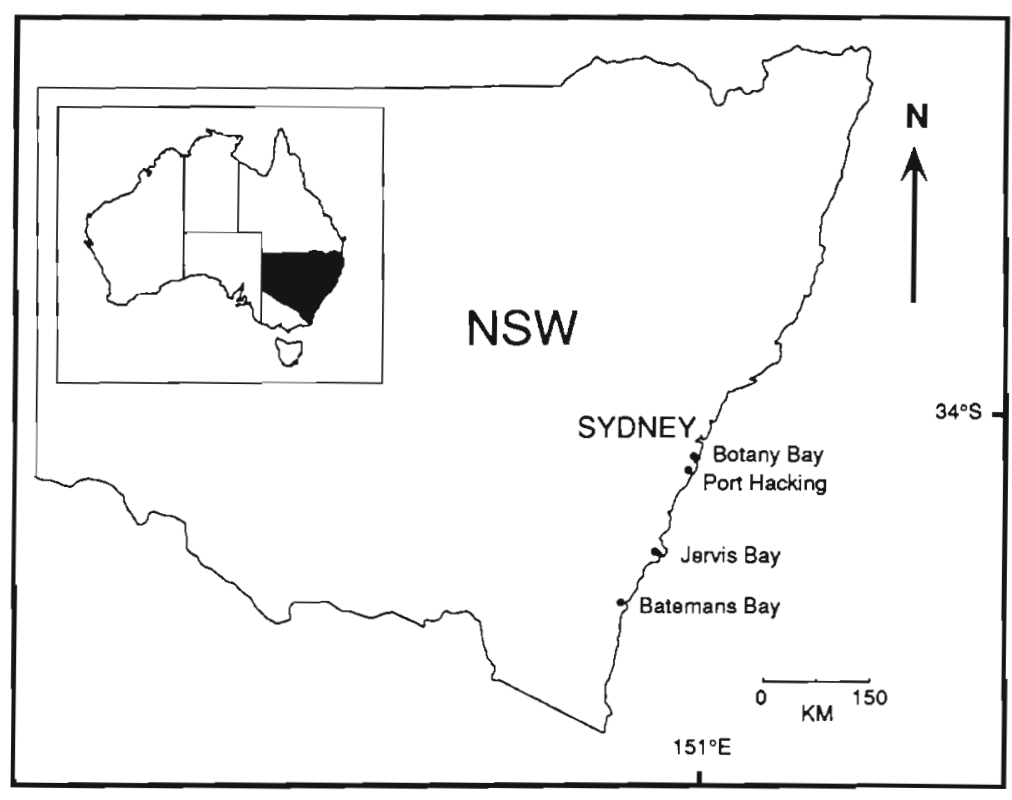

Fig. 1. New South Wales (NSW), Australia, showing the 4 estuaries sampled in this study 
Table 1. Factors in the ANOVAs used for this study, and degrees of freedom for the 2 different analyses. Note that locations are nested within estuaries. $3 \mathrm{H} \times 3 \mathrm{E}$ refers to analysis of all 3 habitats in 3 estuaries (Jervis Bay omitted); $2 \mathrm{H} \times 4 \mathrm{E}$ involves analysis of Zostera and adjacent sand in all 4 estuaries

\begin{tabular}{|lccc|}
\hline \multirow{2}{*}{ Factor } & Type & \multicolumn{3}{c|}{ Analysis and df of $F$-ratio } \\
& & $3 \mathrm{H} \times 3 \mathrm{E}$ & $2 \mathrm{H} \times 4 \mathrm{E}$ \\
\hline Habitat (H) & Fixed & 2,12 & 1,8 \\
Estuary (E) & Fixed & 2,6 & 3,8 \\
Location (Estuary) L(E) & Random & 6,81 & 8,72 \\
$\mathrm{H} \times \mathrm{E}$ & & 4,12 & 3,8 \\
$\mathrm{H} \times \mathrm{L}(\mathrm{E})$ & & 12,81 & 8,72 \\
Residual & & 81 & 72 \\
& & & \\
\hline
\end{tabular}

and distant sand habitats among locations within estuaries, or among estuaries. The variables analysed were: total number of fish species, total abundance of fish, and abundances of common species, i.e. species that occurred in more than 2 estuaries and had more than 50 individuals in total. The ANOVA model we used had locations nested within estuaries, and treated habitats and estuaries as fixed factors. Homogeneity of variance was tested by Cochran's test and data were transformed to $\ln (x+1)$ as necessary. For some species, transformation did not produce homogeneous variances. In such cases, we used ANOVA anyway, because it is fairly robust to departures of variances when sample sizes are equal (Box 1953), but we set $\alpha=0.01$ to compensate for the increased likelihood of Type I error (Underwood 1981). Where ANOVA indicated significant differences among means, the Student-NewmanKeuls (SNK) test was used to distinguish among them.

In Jervis Bay, we could sample from the distant sand habitat at only 2 of the 3 locations. We overcame this problem by analysing the data in 2 major subsets (Table 1). The first included data from all 3 habitats in Botany Bay, Port Hacking and Batemans Bay. In the second analysis, data from Zostera and adjacent sand were compared for all 4 estuaries. This approach gave a more conservative analysis than one in which all levels of each factor were used with unequal sample sizes but meant that data from distant sand in Jervis Bay were not used in ANOVA.

Some species (with total $n>50$ ) did not occur in all habitats and/or all estuaries. When less than $5 \%$ of the total abundance of a species was recorded in a particular estuary or habitat, that level of the factor was not analysed and the degrees of freedom for the test were reduced appropriately.

The Canberra metric dissimilarity index (Ross et al. 1986) was used to distinguish differences in relative abundance and composition of species among estuaries and habitats. All species were included in this
Table 2. Number of species found in each of the 3 habitats across all 4 estuaries. Number of species shared between 2 habitats is shown with dashed lines. Brackets indicate number of species common to all habitats

\begin{tabular}{|c|c|c|c|}
\hline \multirow[t]{2}{*}{ Type of species } & \multicolumn{3}{|c|}{ Habitat } \\
\hline & Zostera & $\begin{array}{l}\text { Adjacent } \\
\text { sand }\end{array}$ & $\begin{array}{l}\text { Distant } \\
\text { sand }\end{array}$ \\
\hline Unique species: & 13 & 7 & 8 \\
\hline Total species: & 44 & 43 & 20 \\
\hline $\begin{array}{l}\text { Species shared } \\
\text { between } 2 \\
\text { habitats: }\end{array}$ & & 16 & \\
\hline $\begin{array}{l}\text { Species shared } \\
\text { among } 3 \\
\text { habitats }\end{array}$ & & 16 & \\
\hline
\end{tabular}

a)

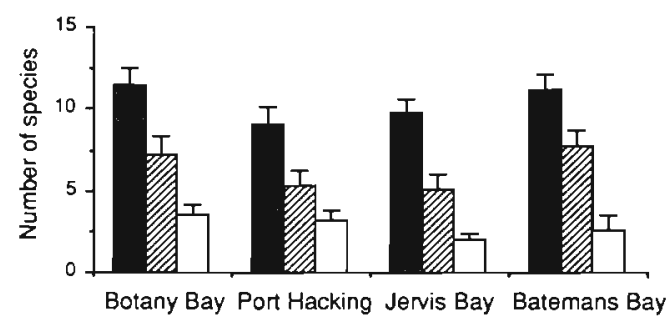

b)

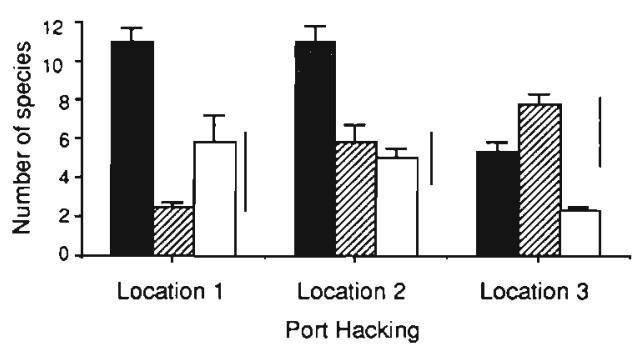

c)

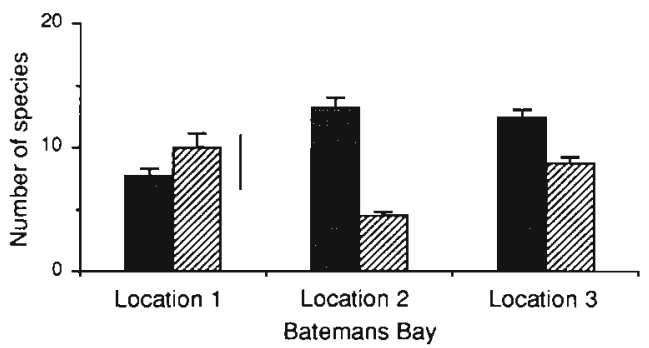

Fig. 2. Mean number of fish species found in (a) 3 habitats in each of 4 estuaries ( $\mathrm{n}=12$ except for distant sand in Jervis Bay where $\mathrm{n}=8$ ); (b) 3 habitats at each of 3 locations in Port Hacking $(\mathrm{n}=4)$ and (c) 2 habitats at 3 locations in Batemans Bay $(n=4)$. Dark histograms: Zostera habitat; hatched: adjacent sand; open: distant sand. Error bars denote the standard error of each mean. Vertical lines adjacent to histograms link means that do not differ significantly at $\alpha=0.05$ by the SNK test 
analysis and abundances of each species were pooled across locations in estuaries and transformed to $\ln (x+1)$

\section{RESULTS}

\section{General description of fauna}

Seventy-one species, and 24623 individual fish, were collected from all locations. Two species, Velambassis jacksoniensis (15 369 individuals) and Myxus elongatus (3202 individuals), dominated the catch. The distributions of these species were very patchy. $V$. jacksoniensis occurred in 70 of 140 hauls, but $>7000$ individuals were taken from Zostera at a single location in Jervis Bay, and 3500 were collected in Zostera at one location in Port Hacking. Similarly, $M$. elongatus was present in 37 of 140 hauls, and 1650 individuals were collected from distant sand in one location in Port Hacking, while 900 were caught from distant sand at one location in Jervis Bay. When $V$. jacksoniensis and $M$. elongatus were excluded, the other 15 common species comprised $>83 \%$ of the remaining catch.

Similar numbers of species were found in Zostera and adjacent sand, and both these habitats had more than twice as many species as did distant sand (Table 2). Many species occurred in 2 or more habitats. The overlap in species between the Zostera and adjacent sand was particularly high (Table 2). Eighteen species were represented by only one individual each.

\section{Variation in mean number of species}

The mean number of species associated with Zostera appeared to be consistently greater than the mean number in the other 2 habitats (Fig. 2a). However, differences in mean numbers of species in Zostera, adjacent sand and distant sand varied among localities within estuaries [see $\mathrm{H} \times \mathrm{L}(\mathrm{E})$ interaction term for the analysis comparing all 3 habitats in Table 3]. Results from Port Hacking (Fig. 2b) provide an example of this variation in differences among habitats from one location to the next: significantly greater numbers of species were found in Zostera than in adjacent sand at only 2 of 3 locations, and adjacent sand had more species than distant sand at only one location. Overall,

a)

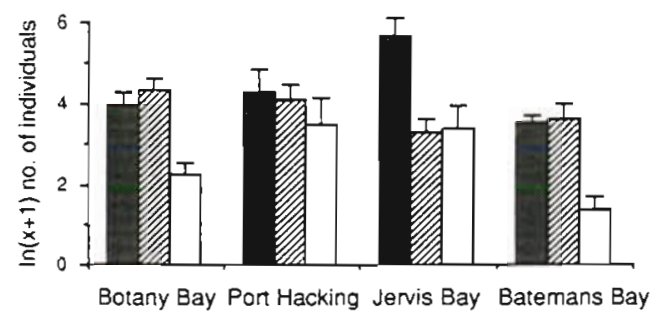

b)

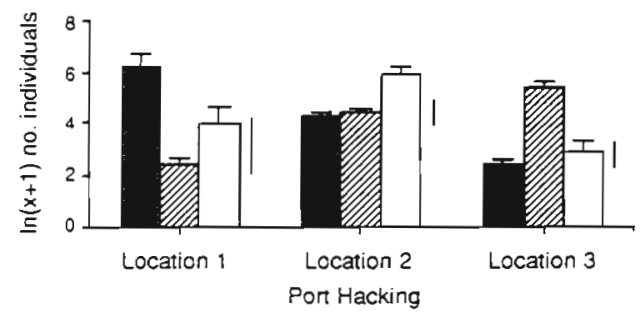

c)

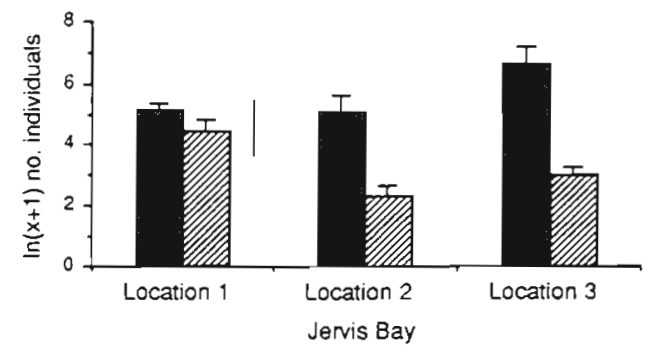

Fig. 3. Mean numbers of total fish individuals found in (a) 3 habitats in each of 4 estuaries; (b) 3 habitats at each of 3 locations in Port Hacking and (c) 2 habitats at 3 locations in Jervis Bay. Sample sizes, shading and symbols as in Fig. 2.

Note that SNK tests were done on transformed data

Table 3. F-ratios from ANOVA for the ' $3 \mathrm{H} \times 3 \mathrm{E}^{\prime}$ and ' $2 \mathrm{H} \times 4 \mathrm{E}$ ' sets of data (see Table 1) for total number of species (Spp.), total number of individuals (Inds.), and total number of individuals excluding Velambassis jacksoniensis and Myxus elongatus (Inds. 2 spp.) A: data transformed to $\ln (x+1) . \cdot p<0.05, \cdots p<0.01$

\begin{tabular}{|c|c|c|c|c|c|c|}
\hline \multirow[t]{3}{*}{ Source } & \multicolumn{6}{|c|}{ Variable } \\
\hline & \multicolumn{2}{|c|}{ Spp. } & \multicolumn{2}{|c|}{ Inds. $A$} & \multicolumn{2}{|c|}{ Inds. -2 spp ${ }^{A}$} \\
\hline & $3 \mathrm{H}$ & $2 \mathrm{HI}$ & $3 \mathrm{H}$ & $2 \mathrm{H}$ & $3 \mathrm{H}$ & $2 \mathrm{H}$ \\
\hline Habitat $\mathrm{H}$ & $14.0^{\circ}$ & $8.2^{\circ}$ & $3.9^{\circ}$ & 0.8 & $7.0^{\cdots}$ & 0.0 \\
\hline Estuary E & 2.5 & 2.9 & 3.0 & 2.1 & 1.0 & 0.9 \\
\hline Location (Estuary) L(E) & 2.0 & 1.8 & $4.2^{\cdots}$ & 1.5 & $10.9^{\cdots}$ & $3.4^{\cdots}$ \\
\hline $\mathrm{H} \times \mathrm{E}$ & 0.2 & 0.0 & 0.4 & 1.1 & 0.2 & 0.4 \\
\hline $\mathrm{H} \times \mathrm{L}(\mathrm{E})$ & $6.9^{\cdots}$ & $7.0^{\cdots}$ & $8.6^{\circ}$ & $8.0^{\cdots}$ & $8.2^{\cdots}$ & $7.2^{*}$ \\
\hline
\end{tabular}


significantly more species were collected from Zostera than from distant sand at 8 of the 9 locations used in the ANOVA. Similarly, adjacent sand had significantly more species than distant sand at 4 of 9 locations. In no case did distant sand support more species than Zostera or adjacent sand.

Results for the comparison of Zostera and adjacent sand across all 4 estuaries were similar; differences between the 2 habitats were not consistent among locations within an estuary (Table 3). In Batemans Bay, for example, Zostera had more species than adjacent sand at only 2 of 3 locations (Fig. 2c). Overall, Zostera had a significantly greater mean number of species than adjacent sand at 7 of 12 locations, and adjacent sand never supported a significantly greater mean number of species than Zostera.

\section{Variation in mean abundance of fish}

Abundant species with patchy distributions can mask patterns in total abundance of the remaining species. Consequently, we have presented results for mean abundance of all fish with and without Velambassis jacksoniensis and Myxus elongatus.

All individuals. The mean total number of fish differed among the 3 habitats (Fig. 3a), but the differences depended on the location within an estuary (Table 3 ). Data from Port Hacking illustrate such differences (Fig $3 b)$. There, a different habitat at each location had a significantly greater mean number of individuals than the other habitats. Considering the 3 estuaries together, Zostera had significantly more individuals than distant sand at 5 of 9 locations, and adjacent sand had significantly greater numbers than distant sand at 5 locations. At one location, distant sand had significantly more individuals than Zostera and adjacent sand.

There were significant differences in mean total number of fish in Zostera and adjacent sand in the analysis based on 4 estuaries, but only for some locations within estuaries (Table 3). For example, significantly more fish were collected in Zostera at just 2 of 3 locations in Jervis Bay (Fig. 3c). Overall, Zostera had significantly more individuals than adjacent sand at 5 of 12 locations, whereas adjacent sand had more individuals at 2 locations.

Total individuals, excluding Velambassis jacksoniensis and Myxus elongatus. When $V$. jacksoniensis and $M$. elongatus were excluded, there were also differences in mean abundance of fish associated with the 3 habitats (Fig. 4a). These differences again depended on the location within an estuary (Table 3). The data from Batemans Bay provide a typical example. There, significantly more fish were collected from Zostera than from distant sand at 2 of 3 locations (Fig.
$4 \mathrm{~b})$. When all 9 locations were considered, this pattern occurred at 6 of them. There were also more individuals in adjacent sand than distant sand at 6 of 9 locations Distant sand never had significantly more individuals than Zostera or adjacent sand.

There were significant differences in mean numbers of individuals found in Zostera and adjacent sand in the analysis across the 4 estuaries. These differences also depended on location within estuary (Table 3). For example, Zostera had significantly more fish than adjacent sand at Location 1 in Port Hacking, but the reverse was true at Location 3 (Fig. 4c). Overall, Zostera had significantly greater numbers of individuals at 3 of 12 locations, whereas adjacent sand had significantly more fish at another 3 locations.

\section{Variation in abundances of common species}

Apart from Velambassis jacksoniensis and Myxus elongatus, the remaining 15 common species fell into 2

a)

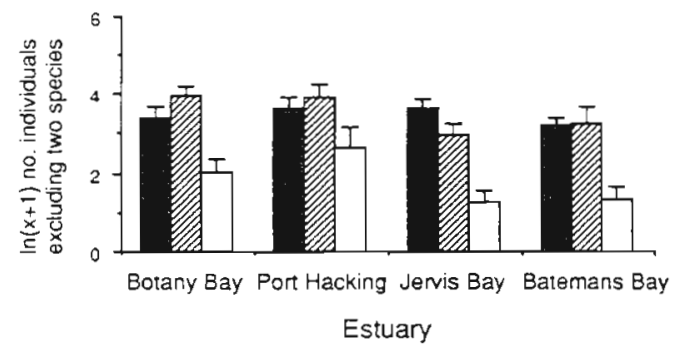

b)

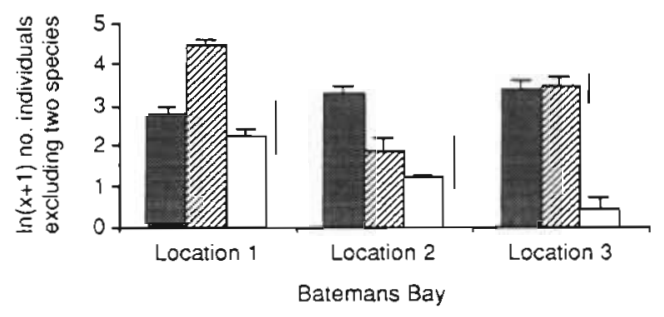

c)

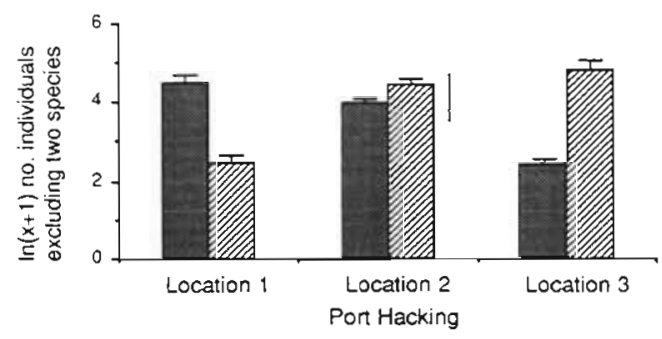

Fig. 4. Mean numbers of total fish individuals, excluding Velambassis jacksonensis and Myxus elongatus, found in (a) 3 habitats in each of 4 estuaries; (b) 3 habitats at each of 3 locations in Batemans Bay and (c) 2 habitats at 3 locations in Port Hacking. Sample sizes, shading and symbols as in Fig. 2. Note that SNK tests were done on transformed data 

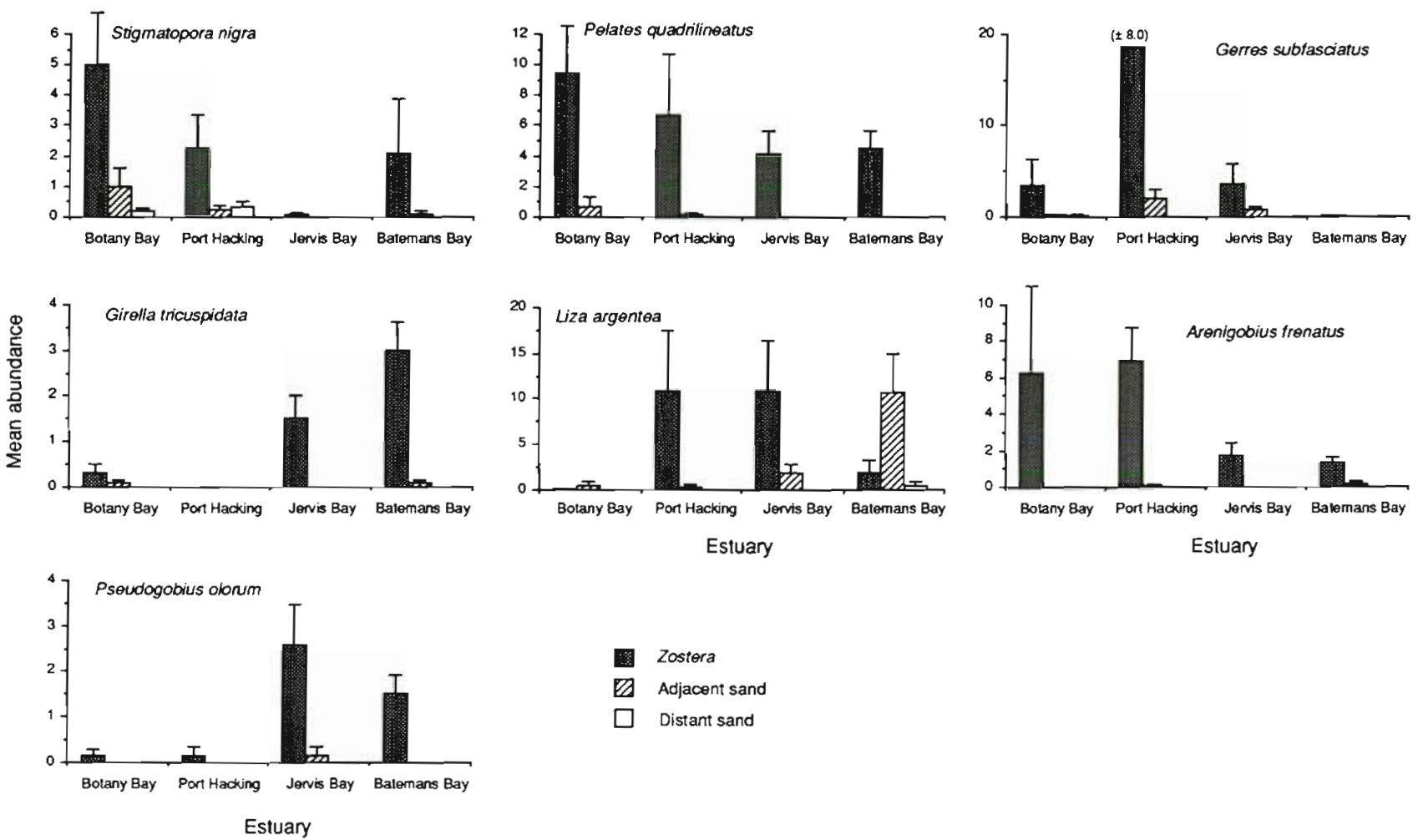

Zastera

B Adjacent sand

Distant sand

Fig. 5. Mean abundances of 7 common species occurring predominantly in Zostera. Sample sizes, shading and symbols as for Fig. $2 a$
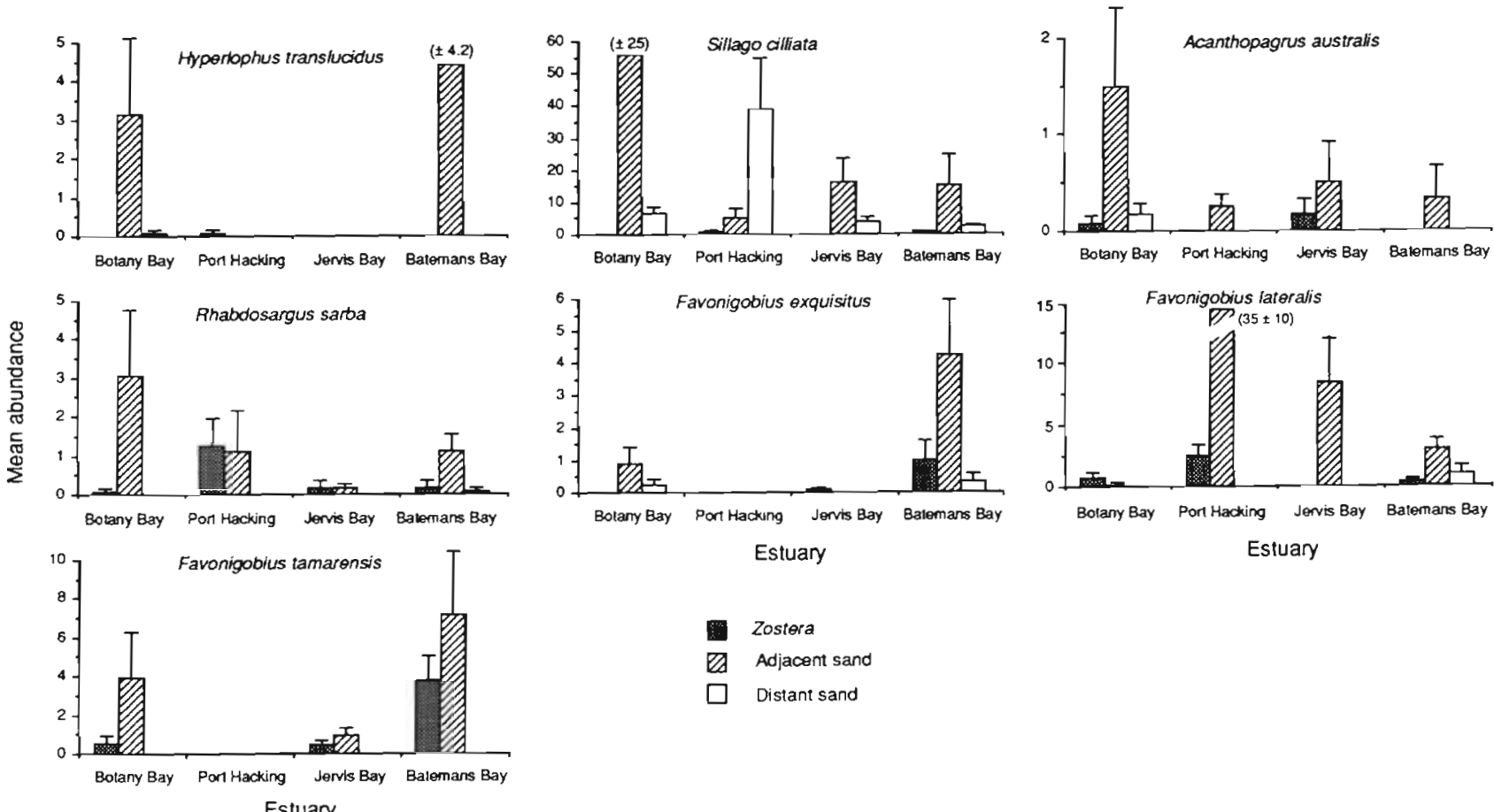

Estuary

Estuary

Zostera

Fig. 6. Mean abundances of 7 common species occurring predominantly in adjacent sand. Sample sizes, shading and symbols as for Fig. 2a 
Table 4. Results of ANOVA for effects of habitats across 4 estuaries for species found predominantly in Zostera or adjacent sand. the model for the analysis and abbreviations are those used in Table 1. Note that the residual degrees of freedom change from 72 to 54 when estuaries where a species was absent are excluded from analysis. ${ }^{\dagger}$ Species with heterogenous variances; significance evaluated at $\alpha=0.01{ }^{~}{ }^{\mathrm{C}}$ Species of commercial or recreational value. $* \mathrm{p}<0.01$

\begin{tabular}{|c|c|c|c|c|c|c|}
\hline Type of species & \multicolumn{5}{|c|}{ Source of variation } & $\begin{array}{l}\text { Residual } \\
\mathrm{df}\end{array}$ \\
\hline $\begin{array}{l}\text { Predominant in Zostera: } \\
\text { Syngnathidae }\end{array}$ & & & & & & \\
\hline Stigmatopora nigra ${ }^{+}$ & - & - & ** & - & $* *$ & 54 \\
\hline $\begin{array}{l}\text { Teraponidae } \\
\quad \text { Pelates quadrilineatus }\end{array}$ & $* *$ & - & ** & - & ** & 72 \\
\hline $\begin{array}{l}\text { Gerridae } \\
\quad \text { Gerres subfasciatus }\end{array}$ & - & - & - & - & ** & 54 \\
\hline $\begin{array}{l}\text { Girellidae } \\
\quad \text { Girella tricuspidata }\end{array}$ & $\star *$ & - & - & - & - & 54 \\
\hline $\begin{array}{l}\text { Mugilidae } \\
\quad \text { Liza argented }\end{array}$ & - & - & ** & - & ** & 54 \\
\hline $\begin{array}{l}\text { Gobiidae } \\
\text { Arenigobius frenatus } \\
\text { Pseudogobius olorum }\end{array}$ & 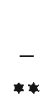 & - & $\begin{array}{l}* * \\
-\end{array}$ & - & ** & $\begin{array}{l}72 \\
72\end{array}$ \\
\hline $\begin{array}{l}\text { Predominant in adjacent sand } \\
\text { Clupeidae } \\
\text { Hyperlophus translucidus }\end{array}$ & - & - & ** & - & ** & 54 \\
\hline $\begin{array}{l}\text { Sillaginidae } \\
\quad \text { Sillago ciliatac }\end{array}$ & $* *$ & - & ** & - & ** & 72 \\
\hline $\begin{array}{l}\text { Sparidae } \\
\text { Acanthopagrus australis }{ }^{\mathrm{c}} \\
\text { Rhabdosargus sarba }\end{array}$ & $\begin{array}{l}- \\
-\end{array}$ & $\begin{array}{l}- \\
-\end{array}$ & * & - & $\begin{array}{l}- \\
-\end{array}$ & $\begin{array}{l}72 \\
72\end{array}$ \\
\hline $\begin{array}{l}\text { Gobiidae } \\
\text { Favonigobius exquisitus }^{\dagger} \\
\text { Favonigobius lateralis } \\
\text { Favonigobius tamarensis }\end{array}$ & $\begin{array}{l}- \\
- \\
-\end{array}$ & $\begin{array}{l}- \\
- \\
-\end{array}$ & $\begin{array}{l}* * \\
* * \\
* *\end{array}$ & $\begin{array}{l}- \\
- \\
-\end{array}$ & $\begin{array}{l}* * \\
* * \\
* *\end{array}$ & $\begin{array}{l}72 \\
54 \\
54\end{array}$ \\
\hline
\end{tabular}

main groups: those found predominantly in either Zostera or adjacent sand. We considered that a species was predominant in a habitat if it occurred there exclusively, or when abundances were greatest in that habitat in the majority of estuaries.

Species occurring predominantly in Zostera. Seven species were collected mainly from Zostera (Fig. 5). In all cases, individuals were scarce in distant sand (Fig. 5) and so data were analysed only for differences between Zostera and adjacent sand across all estuaries. For 5 of the 7 species, there was a significant $\mathrm{H} \times \mathrm{L}(\mathrm{E})$ interaction (Table 4), indicating that Zostera did not support greater numbers of individuals than adjacent sand at all locations within an estuary. For these 5 species, there were 17 combinations of species $\times$ estuary where $>5 \%$ of species abundances could be compared between Zostera and adjacent sand. Thus there were 51 instances where abundances could be compared between Zostera and adjacent sand. In 31 of these comparisons, abundances were significantly greater in Zostera. In all but 2 of the remaining 20 in- stances there was no difference in abundance between Zostera and adjacent sand because fish were absent or very scarce in both habitats.

Abundance of Pseudogobius olorum, one of the remaining 2 species, did not differ significantly among locations within estuaries, but they did differ significantly among habitats and estuaries (Table 4, Fig. 5). For the other species, Girella tricuspidata, abundances were significantly greater in Zostera (Table 4, Fig. 5).

Species occurring predominantly in adjacent sand. Seven species were also collected predominantly from adjacent sand (Fig. 6). Except for Sillago ciliata, these species were also caught only in very low numbers in distant sand, and so analysis was limited to a comparison of Zostera and adjacent sand. There were significant $H \times L(E)$ interactions for 5 of the 7 species (Table $4)$. Thus, abundances were not always greater in adjacent sand than in Zostera at all locations within an estuary. For these 5 species there were 42 instances where abundances from adjacent sand and Zostera could be compared. Abundances were significantly 


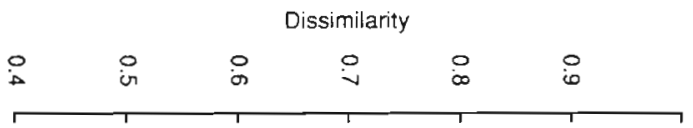

Adjacent sand- Jenvis Bay

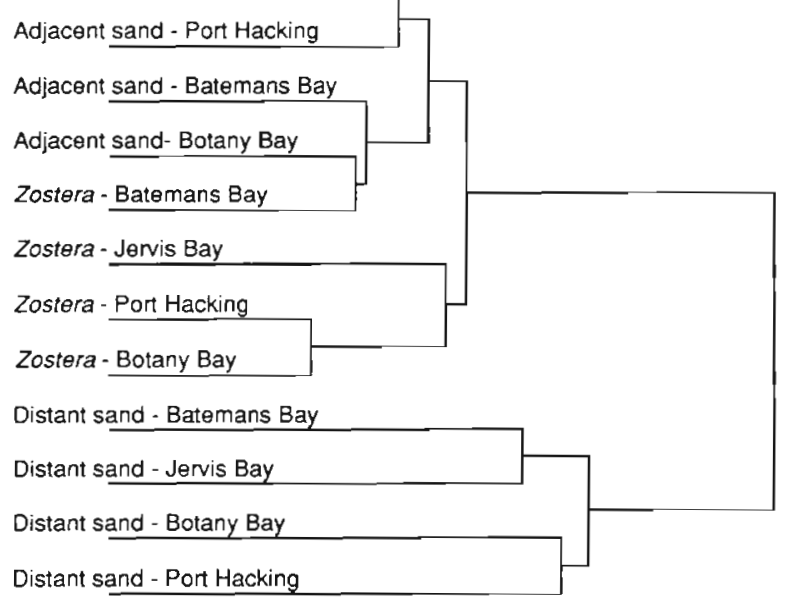

Fig. 7. Dendrogram showing the relative dissimilarity of samples from the 3 habitats in 4 estuaries

greater in adjacent sand than in Zostera for 25 of these. For the remaining 17 instances, there was no difference in abundance between the 2 habitats because fish were absent or very scarce in adjacent sand and Zostera.

The analysis did not demonstrate significant habitat differences ( $\alpha=0.01)$ for Acanthopagrus australis, one of the remaining 2 species (Table 4). For the other species, Rhabdosargus sarba, there was a significant effect for location (Table 4). This was caused by occurrence in both habitats at just one of the 3 locations in Botany Bay.

Other patterns of abundance. The only common species that could not be placed in the above 2 groups was Atherinosoma microstoma. It was present in 2 estuaries. In Port Hacking, it occurred in significantly greater numbers in adjacent sand than in the other 2 habitats. In Botany Bay, abundances were significantly greater in distant sand.

\section{Similarity of fauna among habitats and estuaries}

In all but one case, samples from the same habitat in different estuaries were more similar to one another than to samples from different habitats in the same estuary (Fig. 7). Samples from Zostera in Batemans Bay were the exception; they were more similar to all samples from adjacent sand than to samples from Zostera in other estuaries. The samples from adjacent sand and Zostera were more similar to each other than to those collected from distant sand (Fig. 7).

\section{DISCUSSION}

\section{Differences in diversity, abundance and species composition}

The answer to the question, 'Does seagrass support a greater diversity and abundance of fish than sand over a large spatial scale?', changed depending on how far sand was from seagrass, and the variable chosen to measure use of the habitats. Analysis of mean number of species showed that Zostera supported more species of fish than sand at a majority of locations. This was more apparent for the comparisons between Zostera and distant sand than for those between Zostera and adjacent sand. Zostera had significantly more species than distant sand at 8 of 9 locations, whereas Zostera had more species than adjacent sand at only 7 of 12 locations. The classification analysis clearly separated samples from each of the 3 habitats, irrespective of estuary. This showed that the habitats supported different species, or that there were differences in relative abundance of species among habitats. Note, however, that the fauna from adjacent sand was more similar to that from Zostera than to the fauna from distant sand.

When the total abundance of fish (excluding 2 species with very patchy distributions) was used to compare Zostera and bare sand, the answer to our question was completely different. Zostera did not have significantly greater numbers of fish at a majority of locations. Adjacent sand had significantly more fish than Zostera at 3 locations, the opposite was true at another 3 locations, and there were no significant differences between Zostera and adjacent sand at the remaining 6 locations. Moreover, adjacent sand was as different to distant sand as Zostera was to distant sand, i.e. both habitats had significantly more fish than distant sand at 6 of 9 locations.

The apparently comparable result for total number of fish associated with Zostera and adjacent sand was due mainly to the nature of this variable. It combines abundances of several species, and major problems in interpretation can arise when reciprocal patterns of abundance occur for different species (see Bell \& Westoby 1986a). This was the case here. Although Zostera and adjacent sand had equal abundances of fish at 6 of 12 locations, the 2 habitats had different species of fish. This was evident in analyses of abundances of common species. These species were divided equally into those found predominantly in Zostera or adjacent sand.

In summary, Zostera had more fish species and individuals, and different species of fish, than sand $>100 \mathrm{~m}$ from seagrass at a majority of locations. On the other hand, fish assemblages from sand within $10 \mathrm{~m}$ of Zostera were more similar to those of Zostera than to fish assemblages found over sand further away. 


\section{Variation in use of habitats}

Most common species 'preferred' either Zostera or adjacent sand. However, this was not the case at all locations within an estuary. Although we cannot say exactly why this happened, patterns of abundance for species found predominantly in adjacent sand, or Zostera, provide a possible explanation. For these species, inconsistent results occurred mainly because individuals were absent from both habitats rather than equally abundant in both. Absence of marine species with pelagic larvae from potentially suitable habitats is well documented. There are at least 2 possible reasons: local failure of recruitment (Bell \& Westoby 1986b, Doherty \& Williams 1988, Underwood \& Fairweather 1989) and recruitment to a restricted part of the available habitat (Bell et al. 1988). It is not surprising, therefore, that when abundances of several species were summed over a large number of locations, fish associated with Zostera were, on average, no more numerous than those found over adjacent sand.

The finding that adjacent sand supported comparable numbers, but different species, of fish to Zostera during the day is novel. Bare substrata adjacent to seagrass has been recognised as a foraging habitat for fish associated with seagrass, but only at night (Summerson \& Peterson 1984). Also, Sogard (1989) found that fish readily colonised artificial seagrass placed near real seagrass. Both studies demonstrate that some fish readily leave seagrass and cross nearby bare substrata. Thus we might expect fish caught over adjacent sand to be 'seagrass' fishes. This was not so in southeastern Australia. The species most abundant over adjacent sand were not a subset of species found in both Zostera and sand $<10 \mathrm{~m}$ away. They were found predominantly over adjacent sand.

Seagrass is believed to support diverse and abundant assemblages of fish partly because it offers protection from predators (Bell \& Pollard 1989, and references therein). It is appropriate to ask whether availability of nearby shelter enabled species to use the area immediately around seagrass. Although this cannot be tested without further behavioural studies, existing information suggests it was not the case. All the common species found in adjacent sand had mechanisms for avoiding predation in the absence of shelter. The 3 species of Favonigobius are benthic and highly cryptic against soft substrata. The other 4 species have strong schooling behaviour. The distributions of these fish, most of which are benthic predators (McDonald 1981, Middleton et al. 1984, Robertson 1984, Burchmore et al. 1988), suggest that the supply of food in adjacent sand may be greater than in distant sand. There are no data from Australia to evaluate this, but data from one location overseas show that there was no variation in infauna of sand within $15 \mathrm{~m}$ of the edge of seagrass (Summerson \& Peterson 1984).

An alternative hypothesis is that species predominant in adjacent sand during the day shelter in Zostera at night. This is based on studies of the behaviour of schooling fish, associated with beds of Posidonia in the Mediterranean. These fish occupy the water column during the day and shelter among the seagrass at night (see references in Bell \& Pollard 1989). However, Summerson \& Peterson (1984) found that fish associated with Zostera marina and Halodule wrightii sheltered among the seagrass during the day. Identification of the mechanism(s) accounting for the high density of fish adjacent to Zostera capricorni in southeastern Australia is an important area for future research.

\section{Implications for management}

Bell \& Pollard (1989) provide guide-lines for management of seagrass beds in estuaries to maintain populations of fish. The spatial scale of our study was sufficient to show that Zostera, and the area immediately around it, usually support much greater diversity and numbers of fish than sand $>100 \mathrm{~m}$ away from Zostera. Clearly, areas adjacent to Zostera beds should be managed as carefully as the seagrass itself. This point is reinforced by the fact that 4 of the 7 common species associated with sand within $10 \mathrm{~m}$ of seagrass were of commercial or recreational value. The use of 'edge habitats' among patchy seagrass by fish of economic value has been noted previously, but only for single species (e.g. Holt et al. 1983, Burchmore et al. 1988).

In some situations, managers will have to make decisions about the size of buffer zones around seagrass beds. It is reasonable to assume that developments which cause an impact within $10 \mathrm{~m}$ of Zostera beds have potential to affect large numbers of fish, relative to developments more than $100 \mathrm{~m}$ from seagrass beds. The scale of our study was not fine enough to detect the exact size of the area adjacent to Zostera beds that supports comparable numbers of fish to the seagrass itself. This remains an important question for managers of estuaries in southeastern Australia.

Acknowledgements. We thank S. McNeill, D. Grimma and A. Roach for assistance with collection and identificaticn of samples. Difficult identifications were done by D. Hoese and A. Gill of the Australian Museum. D. Reid and G. Gcrdon assisted with the statistical analyses. N. Andrew, G. Edgar, P. Fairweather, C. Jacoby, R. West, D. Worthington and 2 anonymous referees provided helpful comments on the manuscript. Funding was provided by the Australian Department of Defence in the course of marine ecological studies in Jervis Bay. 


\section{LITERATURE CITED}

Beckley, L. E. (1983). The ichthyofauna associated with Zostera capensis Setchell in the Swartkops estuary. South Africa. S. Afr. J. Zool. 18: 15-24

Bell, J. D., Pollard, D. A. (1989). Ecology of fish assemblages and fisheries associated with seagrasses. In: McComb, A. J., Larkum, A. W. D., Shepherd, S. A. (eds.) The biology of seagrasses: an Australian perspective. Elsevier, Amsterdam, p. 565-609

Bell, J. D., Steffe, A. S., Westoby, M. (1988). Location of seagrass beds in estuaries: effects on associated fish and decapods. J. exp. mar. Biol. Ecol, 122: 127-146

Bell, J. D., Westoby, M. (1986a). Importance of local changes in leaf height and density to fish and decapods associated with seagrasses. J. exp. mar Biol. Ecol. 104: 249-274

Bell, J. D., Westoby, M. (1986b). Variation in seagrass height and density over a wide spatial scale: effects on common fish and decapods. J. exp. mar. Biol. Ecol. 104: 275-295

Bell, J. D., Westoby, M., Steffe, A. S. (1987). Fish larvae settling in seagrass: do they discriminate between beds of different leaf density? J. exp. mar. Biol. Ecol. 111: 133-144

Bennett, B. A. (1989). Fish community of a moderately exposed beach on the southwestern cape coast of South Africa and an assessment of this habitat as a nursery for juvenile fish. Estuar. coast. Shelf Sci. 28: 293-305

Box, G. E. P. (1953). Non-normality and tests on variances. Biometrika 40: 318-335

Branch, G. M. Grindley, J. R. (1979). Ecology of southern African estuaries, Part XI. Mangazana: a mangrove estuary in Transkei. S. Afr. J. Zool. 14: 149-170

Burchmore, J. J., Pollard, D. A., Middleton, M. J., Bell, J. D., Pease, B. C. (1988). Biology of four species of whiting (Pisces: Sillaginidae) in Botany Bay, New South Wales. Aust. J. mar. Freshwat. Res. 39: 709-727

Doherty, P. J., Williams, D. McB. (1988). The replenishment of coral reef fish populations. Oceangr. mar. Biol. A. Rev. 26: $487-551$

Hanekom, N., Baird, D. (1984). Fish community structures in Zostera and non-Zostera regions of the Kromme estuary, St Francis Bay. S. Afr. J. Zool. 19: 295-301

Heck, K. L. Jr, Able, K. W., Fahay, M. P., Roman, C. T. (1989). Fishes and decapod crustaceans of Cape Cod eelgrass meadows: species composition, seasonal abundance patterns and comparison with unvegetated substrates. Estuaries 12: 59-65

Heck, K. L. Jr, Thoman, T A. (1984). The nursery role of seagrass meadows in the upper and lower reaches of the Chesapeake Bay. Estuaries 7: 70-92

Holt, S. A., Kitting, C. L., Annold, C. R. (1983). Distribution of young red drums among different sea-grass meadows. Trans. Am. Fish. Soc. 112: 267-271

Kikuchi, T. (1966). An ecological study on animal communities of the Zostera marina belt in Tomioka Bay, Amakusa, Kyushu. Publ. Amakusa Mar. Biol. Lab. 1: 1-106

This article was presented by A. J. Underwood, Sydney, Australia
Kikuchi, T., Peres J. M. (1977). Consumer ecology of seagrass beds. In: McRoy, C. P., Helfferich, C. (eds.) Seagrass ecosystems: a scientific perspective. Dekker, New York, p. $147-193$

McDonald, G. (1981). The ecology of three species of goby (Teleostei, Gobiidae) in Careel Bay, N.S.W. Ph.D. thesis, University of Sydney

MCRoy, C. P., Helfferich, C. (1980). Applied aspects of seagrasses. In: Phillips, R. C., McRoy, C. P. (eds.) Handbook of seagrass biology: an ecosystem perspective. Garland STM Press, New York, p. 297-343

Middleton, M. J., Bell, J. D., Burchmore, J. J., Pollard, D. A., Pease, B. C. (1984), Structural differences in the fish communities of Zostera capricorni and Posidonia australis seagrass meadows in Botany Bay, New South Wales. Aquat. Bot. 18: 89-109

Orth, R. J., Heck, K. L. Jr. (1980). Structural components of the eelgrass (Zostera marina) meadows in the lower Chesapeake Bay - fishes. Estuaries 3: 278-288

Orth, R. J., Heck, K. L. Jr, Van Montfrans, J. V. (1984). Faunal communities in seagrass beds: a review of the influence of plant structure and prey characteristics on predator-prey relationships. Estuaries 7: 339-350

Robertson, A. I. (1980). The structure and organisation of an eelgrass fish fauna. Oecologia (Berl.) 47: 76-82

Robertson, A. I. (1984). Trophic interaction between the fish fauna and the macrobenthos of an eelgrass community in Westernport, Victoria. Aquat. Bot. 18: 135-153

Robertson, A. I., Lenanton, R. C. J. (1984). Fish community structure and food chain dynamics in the surf-zone of sandy beaches: the role of detached macrophyte detritus. J. exp. mar. Biol. Ecol. 84: 265-283

Ross, D., Dale, M., Shields, K., Juleh, C. (1986). Taxon users manual, Edition P4. CSIRONET Reference Manual No. 6. CSIRO, Melbourne

Sogard, S. M. (1989). Colonization of artificial seagrass by fishes and decapod crustaceans: importance of proximity to natural eelgrass. J. exp. Mar. Biol. Ecol. 133: 15-37

Stoner, A. W. (1983). Distribution of fishes in seagrass meadows: role of macrophyte biomass and species composition. Fish. Bull. U. S. 81: 837-846

Summerson, H. C., Peterson, C. H. (1984). Role of predation in organizing benthic communities of a temperate-zone seagrass bed. Mar. Ecol. Prog. Ser. 15: 63-77

Underwood, A. J. (1981). Techniques for analysis of variance in experimental marine biology and ecology. Oceanogr. mar. Biol. A. Rev. 19: 513-605

Underwood, A. J., Fairweather, P. G. (1989). Supply-side ecology and benthic marine assemblages. Trends Ecol. Evol. 4: 16-20

Whitfield, A. K., Beckley, L. E., Bennett, B. A., Branch, G. M., Kok, H. M., Potter, I. C. Van Der Elst, R. P. (1989). Composition, species richness and similarity of ichthyofauna in eelgrass Zostera capensis beds of South Africa. S. Afr. J. mar. Sci. 8: 251-259

Manuscript first received: May 23, 1990

Revised version accepted: March 1, 1991 